\title{
Comparison of three strip-type tests and two laboratory methods for salivary buffering analysis
}

\author{
Zeinab Cheaib • Carolina Ganss • Andreas Lamanda • \\ Melek Dilek Turgut $\cdot$ Adrian Lussi
}

Received: 2 September 2010/Accepted: 17 December 2010/Published online: 10 May 2011

(C) The Society of The Nippon Dental University 2011

\begin{abstract}
This study evaluated the correlation between three strip-type, colorimetric tests and two laboratory methods with respect to the analysis of salivary buffering. The strip-type tests were saliva-check buffer, Dentobuff strip and CRT $^{\circledR}$ Buffer test. The laboratory methods included Ericsson's laboratory method and a monotone acid/base titration to create a reference scale for the salivary titratable acidity. Additionally, defined buffer solutions were prepared and tested to simulate the carbonate, phosphate and protein buffer systems of saliva. The correlation between the methods was analysed by the Spearman's rank test. Disagreement was detected between buffering capacity values obtained with three strip-type tests that was more pronounced in case of saliva samples with medium and low buffering capacities. All striptype tests were able to assign the hydrogencarbonate, $d i$-hydrogenphosphate and $0.1 \%$ protein buffer solutions to the correct buffer categories. However, at $0.6 \%$ total
\end{abstract}

Z. Cheaib $(\bowtie) \cdot$ A. Lussi

Department of Preventive, Restorative and Pediatric Dentistry, University of Bern, Freiburgstrasse 7, 3010 Bern, Switzerland e-mail: zeinab.cheaib@zmk.unibe.ch

\section{Ganss}

Department of Conservative and Preventive Dentistry, Dental Clinic, Justus Liebig University, Giessen, Germany

A. Lamanda

Mühlegasse 22, 3400 Burgdorf, Switzerland

M. D. Turgut

Department of Paediatric Dentistry, Faculty of Dentistry, Hacettepe University, Ankara, Turkey protein concentrations, none of the test systems worked accurately. Improvements are necessary for strip-type tests because of certain disagreement with the Ericsson's laboratory method and dependence on the protein content of saliva.

Keywords Strip-type test - Buffer capacity . Buffer value $\cdot$ Human saliva $\cdot$ Titratable acidity

\section{Introduction}

Although dental caries is considered to be the most common disease affecting the human race, the prevalence of dental erosion has been increasing steadily [1, 2]. Dental caries and erosion are known to be multifactorial diseases [2, 3]. To prevent further progression of both entities, it is important to detect the risk factors as early as possible so that appropriate preventive measures can be initiated. In both cases, nutritional and patient-related factors are of importance [4, 5]. While nutritional factors may be changed by the patients, physiological features such as saliva or its buffering capacity are difficult to be improved. Saliva is vital for the maintenance of the integrity for the teeth and the soft tissues. Its lubricating effect keeps the oral mucosa moist and helps in eating, swallowing and washing away food remnants trapped in inaccessible intraoral sites. In addition, its neutralising and remineralising properties are of utmost importance for healthy tooth structures [6]. The quality and quantity of saliva are the main parameters to consider [7]. The quality of saliva is defined by its protein content, viscosity, $\mathrm{pH}$ and buffering capacity, but the quantity is related mostly to the flow rate. The latter is the main subject at numerous clinical investigations [3]. 
The buffering capacity is one of the many parameters monitored in the clinic. It has been recommended to be a part of caries risk assessment, although the relationship between salivary buffering and caries is controversial and frequently discussed [3, 8]. Recent findings showed that low buffer capacity was significantly associated with severe erosion $[2,9]$. In this study, normal salivary flow was found in $92 \%$, but low salivary buffering $(10.4 \%)$ was associated with erosion into the dentin [9].

The buffering capacity of saliva involves three buffer systems, namely the carbonate, phosphate and protein buffers $[10,11]$. These systems work in different $\mathrm{pH}$ ranges. While the optimal buffering for the phosphate and carbonate systems occurs at $\mathrm{pH} 7.2$ and 6.3, respectively $\left(25^{\circ} \mathrm{C}\right)$, buffering below pH 5 is based on the protein system [10]. To assess the buffering capacity of saliva, Ericsson's laboratory method is accepted as the gold standard [12]. The method is based on the measurement of the salivary $\mathrm{pH}$ value after a certain amount of $\mathrm{HCl}$ is added to collected saliva, followed by a waiting period of $20 \mathrm{~min}$ for the elimination of carbon dioxide. The $\mathrm{pH}$ value is then measured, and the buffering capacity is labelled as high, medium or low according to defined $\mathrm{pH}$ values [12]. Since this analytical method is time-consuming and requires a specific device for $\mathrm{pH}$ measurement, colorimetric or so-called strip-type buffer tests have been developed with the aim of simplifying the procedure. They are commonly used to determine the salivary buffering capacity level for the assessment of the caries risk of an individual [13]. These tests follow the principle of a reverse titration. Accordingly, a thin carrier layer containing a dried acid and an indicator is soaked with one drop of saliva for a defined time. During this time period, the acid is neutralised by the salivary buffer systems. Depending on the extent of neutralisation, a colour change occurs. The colour is compared with those on the three-step colour code chart and thus the buffering capacity is categorised as low, medium or high [14]. Although the technique seems to be simple, incorrect categorisation of the saliva samples sometimes occur. Moreover, there may be disagreements between the categories or category labels among different brands.

To the best of our knowledge, no thorough comparison of a correlation between various salivary buffering capacity measurement procedures has been made. Therefore, the aims of the current study were: (1) to evaluate the correlation between three strip-type buffer tests and two quantitative laboratory methods using human saliva; (2) to determine whether the strip-type tests are able to assign the artificial buffer solutions to the correct buffer categories; (3) to give preliminary estimation of the reasons for disagreement between different analytical procedures.

\section{Materials and methods}

Saliva samples

A total of 31 unmedicated healthy volunteers, aged 25 to 50 years, participated in the study. They refrained from eating, drinking, smoking and performing oral hygiene procedures for $2 \mathrm{~h}$ before saliva collection. All samples were collected over $5 \mathrm{~min}$, under standard paraffin stimulated conditions, between 9:00 and 10:00 a.m. [15]. Ethical approval was obtained from the Ethical Committee of Bern University, Switzerland (No. 012/07). The procedures were explained to the subjects and their consent obtained.

All experiments were performed by one investigator and carried out in open system. The buffer capacity of the saliva samples, defined buffer solutions and purified human salivary proteins, were assessed by three strip-type colorimetric tests and two quantitative laboratory methods.

Precipitation, dialysis and quantification of salivary proteins

Ammonium sulphate (Merck for analysis, Damstadt, Germany) was added to $10 \mathrm{ml}$ of freshly collected stimulated saliva under constant stirring at $4^{\circ} \mathrm{C}$. When $75 \%$ ammonium sulphate saturation was obtained, the mixture was stirred for an additional period of $30 \mathrm{~min}$. After centrifugation at $14000 \mathrm{rpm}$ on a Hicen 21 centrifuge (Jepson Bolton, Watford, England) for $30 \mathrm{~min}$ at $4^{\circ} \mathrm{C}$, the supernatant was removed and the precipitate was dissolved in $5 \mathrm{ml}$ of deionised water. To remove all inorganic ions, the solution was dialysed at $4^{\circ} \mathrm{C}$ (Sigma dialysis sacks D6191-25EA, Sigma, Buchs, Switzerland) against deionised water overnight. After dialysis, the volume of the dialysed solution was adjusted to $10 \mathrm{ml}$ and used as a buffer solution [16]. The salivary protein concentration was determined according to the Bradford method [17].

\section{Defined buffer solutions}

Defined buffer solutions were used to simulate the carbonate, phosphate and protein buffer systems of saliva. Therefore, they were tested both individually and in various combinations of concentrations known to be typical for saliva [16].

For the protein buffer system, amyloglucosidase, lysozyme and $\alpha$-amylase were tested. For this purpose, amyloglucosidase from Aspergillus niger, lysozyme from hen egg and $\alpha$-amylase from Bacillus subtilis (Fluka Biochemika, Buchs, Switzerland) were used.

The solutions were prepared as follows. 
Di-hydrogenphosphate solution

In $1000 \mathrm{ml}$ of deionised water, $0.41 \mathrm{~g}(3 \mathrm{mmol} / \mathrm{l})$ or $0.68 \mathrm{~g}$ ( $5 \mathrm{mmol} / \mathrm{l}) \quad \mathrm{KH}_{2} \mathrm{PO}_{4}$ (Merck for analysis, Dietikon, Switzerland) was dissolved.

\section{Hydrogencarbonate solution}

In $1000 \mathrm{ml}$ of deionised water, $0.42 \mathrm{~g}(5 \mathrm{mmol} / \mathrm{l}), 0.84 \mathrm{~g}$ $(10 \mathrm{mmol} / \mathrm{l}), 1.68 \mathrm{~g}(20 \mathrm{mmol} / \mathrm{l}), 3.36 \mathrm{~g}(40 \mathrm{mmol} / \mathrm{l})$ or $5.04 \mathrm{~g}(60 \mathrm{mmol} / \mathrm{l})$ of $\mathrm{NaHCO}_{3}$ (Merck for analysis, Dietikon, Switzerland) was dissolved.

\section{Hydrogencarbonate and di-hydrogenphosphate solutions}

In $1000 \mathrm{ml}$ of deionised water, $0.42 \mathrm{~g}(5 \mathrm{mmol} / \mathrm{l}) \mathrm{NaHCO}_{3}$ and $0.68 \mathrm{~g} \quad(5 \mathrm{mmol} / \mathrm{l}) \quad \mathrm{KH}_{2} \mathrm{PO}_{4}, \quad 0.84 \mathrm{~g} \quad(10 \mathrm{mmol} / \mathrm{l})$ $\mathrm{NaHCO}_{3}$ and $0.41 \mathrm{~g}(3 \mathrm{mmol} / \mathrm{l}) \quad \mathrm{KH}_{2} \mathrm{PO}_{4}, \quad 1.68 \mathrm{~g}$ (20 mmol/l) $\mathrm{NaHCO}_{3}$ and $0.41 \mathrm{~g}(3 \mathrm{mmol} / \mathrm{l}) \mathrm{KH}_{2} \mathrm{PO}_{4}$, $3.36 \mathrm{~g} \quad(40 \mathrm{mmol} / \mathrm{l}) \quad \mathrm{NaHCO}_{3}$ and $0.41 \mathrm{~g} \quad(3 \mathrm{mmol} / \mathrm{l})$ $\mathrm{KH}_{2} \mathrm{PO}_{4}$, or $5.04 \mathrm{~g}(60 \mathrm{mmol} / \mathrm{l}) \mathrm{NaHCO}_{3}$ and $0.41 \mathrm{~g}$ (3 mmol/l) $\mathrm{KH}_{2} \mathrm{PO}_{4}$ were dissolved.

\section{Salivary protein solution}

The freshly prepared salivary proteins from $10 \mathrm{ml}$ of saliva (as described before) were dissolved in $10 \mathrm{ml}$ of deionised water.

\section{Artificial protein solutions}

In $10 \mathrm{ml}$ of deionised water, $0.01 \mathrm{~g}(0.1 \%, 10.2 \mu \mathrm{mol} / \mathrm{l})$ amyloglucosidase from $A$. niger and $0.05 \mathrm{~g}(0.5 \%$, $342 \mu \mathrm{mol} / \mathrm{l})$ lysozyme from hen egg were dissolved.

\section{$\alpha$-Amylase solution}

In $10 \mathrm{ml}$ of deionised water, $0.01 \mathrm{~g},(0.1 \%, 13.7 \mu \mathrm{mol} / \mathrm{l})$ of $\alpha$-amylase from $B$. subtilis was dissolved.

\section{Hydrogencarbonate, di-hydrogenphosphate and protein solutions}

In $10 \mathrm{ml}$ of deionised water, $0.84 \mathrm{~g} \quad(10 \mathrm{mmol} / \mathrm{l})$ $\mathrm{NaHCO}_{3}, 0.41 \mathrm{~g}(3 \mathrm{mmol} / \mathrm{l}) \mathrm{KH}_{2} \mathrm{PO}_{4}$ and $0.01 \mathrm{~g}(0.1 \%$, $10.2 \mu \mathrm{mol} / \mathrm{l})$ amyloglucosidase from $A$. niger and $0.05 \mathrm{~g}$ $(0.5 \%, 342 \mu \mathrm{mol} / \mathrm{l})$ lysozyme from hen egg were dissolved.

After adjustment to $\mathrm{pH}=7$, all solutions were stored in gas-proof closed vessels.
Laboratory reference methods

\section{Titration method}

Two $\mathrm{ml}$ of the analytes (saliva, defined buffer solution or purified human salivary proteins) was placed in a vessel in a water bath and stirred at $37^{\circ} \mathrm{C}$. First, $1 \mathrm{ml}$ of $\mathrm{NaOH}$ ( $0.01 \mathrm{~mol} / \mathrm{l})$ was added to approach the buffer range of $d i$ hydrogenphosphate $(\mathrm{pH} 6.2-8.2)$, and then $6 \mathrm{ml}$ of $\mathrm{HCl}$ $(0.01 \mathrm{~mol} / \mathrm{l})$ was added in steps of $40 \mu \mathrm{l}$. The $\mathrm{pH}$ value was measured after each addition step by an automated titration system (Mettler-Toledo DL53 and Software Lab X pro V 2.10.000). The amount of acid or base used was plotted against the measured $\mathrm{pH}$. The obtained titration curve was used to determine the titratable acidity. For the determination of the titratable acidity, the first derivative $\left(y^{\prime}=\Delta \mathrm{pH} /\right.$ $\Delta C$ ) was plotted against the $\mathrm{pH}$. The inflection coordinates were taken at the point of the highest slope. $\Delta C$ is the amount of the titrator used (acid/base), and $\Delta \mathrm{pH}$ is the change in $\mathrm{pH}$ caused by the addition of the titrator. The reference measured by acid base titration was used to create an analogue scale for the titratable acidity of the saliva samples.

\section{Ericsson method}

One $\mathrm{ml}$ of saliva or one of the defined buffer solutions was placed in a tube with $3 \mathrm{ml}$ of $\mathrm{HCl}(0.005 \mathrm{~mol} / \mathrm{l})$. After a waiting period of $20 \mathrm{~min}$ for the elimination of carbon dioxide by air bubbling, the $\mathrm{pH}$ of the solution was measured. $\mathrm{pH}$ values $\geq 5.6$ were considered as "high", whereas those ranging from 4.1 to 5.5 were labelled as "medium" and those $\leq 4$ were defined as "low" [18].

\section{Colorimetric strip-type tests}

Each sample was tested twice with the laboratory methods and strip-type tests. In the event that an inconsistent colour was obtained with a strip-type test (in 6 cases), it was repeated a third time to make a decision about the colour of the sample.

\section{Saliva-check buffer (GC Corporation, Tokyo, Japan)}

The strips were placed on an absorbent surface. One drop of saliva or defined buffer solution was dispensed onto the three test pads of one strip. Then, the strips were rotated by $90^{\circ}$ to remove excess saliva from the test pads to the absorbent surface. After 2 min, the colour of each of the three test pads on each strip was assigned to the standard colour chart and the corresponding numerical value. The mean of the three numerical values was calculated to obtain the final result (very low, low and normal/high). 


\section{Dentobuff strip (Orion Diagnostica, Espoo, Finland)}

The strips were placed on an absorbent surface. One drop of saliva or defined buffer solution was dispensed onto the test pad. After $5 \mathrm{~min}$, the colour of the test pads on each strip was assigned to the standard colour chart to obtain the final result (low, intermediate, high).

\section{$C R T^{\circledR}$ buffer test (Ivoclar Vivadent, Schaan, Liechtenstein)}

The strips were placed on an absorbent surface. One drop of saliva or defined buffer solution was dispensed onto the test pad. Then, the strips were rotated by $90^{\circ}$ to remove excess saliva from the test pads to the absorbent surface. After $5 \mathrm{~min}$, the colour of the test pads on each strip was assigned to the standard colour chart to obtain the final result (low, medium, high).

\section{Statistical evaluation}

The results from five test systems obtained for human saliva were sorted according to the ascending titratable acidity values obtained by the reference method ranging from 10 to $22.6 \mathrm{mmol} / \mathrm{l}$ (No. 1-31). To make a statistical comparison, the colour code value was replaced with numerical values 1,2 or 3 (Table 1 ). The titratable acidity was referred to ranks 1, 2 or 3 according to the Ericsson method and the results were then subjected to Spearman's rank correlation. The level of significance was set at $\alpha=0.001$.

\section{Disagreement}

The disagreement referred to the discrepancy between category numbers was defined by different applied tests for the same probe. For example, intermediate level of buffering capacity (category 2) was detected for subject 2 (see Table 2) by Dentobuff strip, while other tests showed low buffering capacity (category 1). This is considered as a disagreement and shown by an asterisk in Table 2.

\section{Results}

Human saliva samples

Table 2 shows the results sorted according to the ascending titratable acidity values determined by the reference method. When the different methods were compared, some disagreements $(*)$ were obvious. In the range from 11 to $17 \mathrm{mmol} / \mathrm{l}, 10$ test disagreements were detected and marked with asterisks in Table 2. The different test systems had an overlapping zone of 1.6 and $6.6 \mathrm{mmol} / \mathrm{l}$ for category 1 (low, very low) and for category 3 (high, normal/high), respectively. In category 2 (medium, intermediate, low), the overlapping zone of all tested systems was only $0.6 \mathrm{mmol} / \mathrm{l}$ (Fig. 1, zone II).

A summary of the correlations among the test systems is shown in Table 3. There was no significant difference between the results of the three strip-type tests and Ericsson's laboratory method ( $p<0.001)$. The highest correlation between two tests was found for Ericsson and titration methods.

\section{Defined buffer solutions}

For $20 \mathrm{mmol} / \mathrm{l}$ hydrogencarbonate, the data of the Dentobuff strip did not correspond to the result obtained by the Ericsson method. The buffering capacity of $10 \mathrm{mM}$ $\mathrm{NaHCO}_{3}, 3 \mathrm{mM} \mathrm{KH} \mathrm{KH}_{4}, 0.1 \%$ amyloglucosidase and $0.5 \%$ lysozyme for $\mathrm{CRT}^{\circledR}$ buffer and Dentobuff strip tests disagreed with that obtained by the Ericsson method. Furthermore, the buffering capacity of $0.1 \%$ amyloglucosidase and $0.5 \%$ lysozyme was not measurable by salivacheck buffer (Table 4).

\section{Discussion}

The current study evaluated the correlation between three commercially available strip-type saliva buffer test systems and laboratory-based buffer methods. The results of this study revealed that all of the strip-type tests used were faster, less labour intensive and easier to handle than the

Table 1 Assigned categories of the buffering capacity for Ericsson's method, CRT ${ }^{\circledR}$ buffer, Dentobuff strip and saliva-check buffer

\begin{tabular}{lllll}
\hline Category & Ericsson method & CRT $^{\circledR}$ buffer & Dentobuff strip & Saliva-check buffer \\
\hline 1 & Low & Low & Low & Very low \\
2 & Medium & Medium & Intermediate & Low \\
3 & High & High & High & Normal/high \\
\hline
\end{tabular}


Table 2 Allocation of human saliva buffering capacity to the different categories using three strip-type tests as well as two laboratory test methods

Disagreements are marked with asterisk

\begin{tabular}{|c|c|c|c|c|c|c|}
\hline $\begin{array}{l}\text { Subject } \\
\text { no. }\end{array}$ & $\begin{array}{l}\text { Titratable } \\
\text { acidity } \\
(\mathrm{mmol} / \mathrm{l})\end{array}$ & $\begin{array}{l}\text { Ericsson } \\
\text { method } \\
\text { (rank) }\end{array}$ & $\begin{array}{l}\text { CRT }^{\circledR} \\
\text { buffer } \\
\text { (rank) }\end{array}$ & $\begin{array}{l}\text { Dentobuff } \\
\text { strip } \\
\text { (rank) }\end{array}$ & $\begin{array}{l}\text { Saliva-check } \\
\text { buffer (rank) }\end{array}$ & Disagreement \\
\hline 1 & 10 & 1 & 1 & 1 & 1 & \\
\hline 2 & 11 & 1 & 1 & 2 & 1 & $*$ \\
\hline 3 & 11 & 1 & 2 & 2 & 2 & $*$ \\
\hline 4 & 11.4 & 1 & 1 & 1 & 1 & \\
\hline 5 & 11.6 & 1 & 1 & 1 & 1 & \\
\hline 6 & 11.6 & 1 & 1 & 1 & 1 & \\
\hline 7 & 11.8 & 1 & 1 & 1 & 2 & $*$ \\
\hline 8 & 12.2 & 1 & 1 & 2 & 2 & $*$ \\
\hline 9 & 13.4 & 2 & 2 & 2 & 2 & \\
\hline 10 & 13.4 & 2 & 2 & 2 & 2 & \\
\hline 11 & 13.6 & 2 & 2 & 2 & 2 & \\
\hline 12 & 14 & 2 & 2 & 2 & 2 & \\
\hline 13 & 14.2 & 2 & 2 & 3 & 2 & $*$ \\
\hline 14 & 14.4 & 2 & 2 & 3 & 2 & $*$ \\
\hline 15 & 14.6 & 2 & 2 & 3 & 2 & $*$ \\
\hline 16 & 14.6 & 2 & 2 & 2 & 2 & \\
\hline 17 & 15.4 & 2 & 2 & 2 & 2 & \\
\hline 18 & 16 & 3 & 3 & 3 & 3 & \\
\hline 19 & 16.6 & 3 & 2 & 3 & 3 & $*$ \\
\hline 20 & 16.6 & 3 & 3 & 3 & 3 & \\
\hline 21 & 16.8 & 2 & 1 & 2 & 2 & $*$ \\
\hline 22 & 16.8 & 3 & 3 & 3 & 3 & \\
\hline 23 & 17 & 3 & 2 & 3 & 3 & $*$ \\
\hline 24 & 17 & 3 & 3 & 3 & 3 & \\
\hline 25 & 17 & 3 & 3 & 3 & 3 & \\
\hline 26 & 17.2 & 3 & 3 & 3 & 3 & \\
\hline 27 & 17.6 & 3 & 3 & 3 & 3 & \\
\hline 28 & 17.6 & 3 & 3 & 3 & 3 & \\
\hline 29 & 20.6 & 3 & 3 & 3 & 3 & \\
\hline 30 & 20.6 & 3 & 3 & 3 & 3 & \\
\hline 31 & 22.6 & 3 & 3 & 3 & 3 & \\
\hline
\end{tabular}

laboratory methods. Moreover, the costs of all three striptype tests for one saliva sample were approximately in the same range. The costs of the laboratory methods, on the other hand, were estimated to be much higher.

In 31 patients, 10 disagreements were found (32\%) when human saliva was assessed. This implies a low level of agreement from a clinical point of view, although the statistical analysis showed significant correlation. The Ericsson method had one outlier when compared with the monotone titration. Nevertheless, Ericsson method is considered as a gold standard.

The buffering capacity and saliva flow rate of a patient provide information and help dentists in determining proper preventive dental programmes [19, 20]. The medium and low buffering capacities are of importance for dental health. It has been recently shown that low buffering capacity is associated with more severe grades of erosion [9], a fact that may explain the earlier anomalous findings concerning the association between salivary buffering capacity and dental erosion [9]. In this study, the salivary buffering capacity judged by the Dentobuff strip test as high (category 3 from 14.2 to $14.6 \mathrm{mmol} / \mathrm{l}$ ) was classified as category 2 with all other test systems. Similarly, according to saliva-check buffer test, the buffer range from 11.8 to $12.2 \mathrm{mmol} / \mathrm{l}$ was assigned to category 2 (labelled with low), whereas the same buffer range was assigned to category 1 and category 2 by the Dentobuff strip test (labelled with low and intermediate) and to category 1 by the $\mathrm{CRT}^{\circledR}$ Buffer and Ericsson method (labelled with low). Therefore, it seems reasonable to seek for the proper striptype test. In this regard, Dentobuff strip test, for instance, showed low levels of agreement of medium category and 
Fig. 1 Allocation of human saliva to the different categories using three strip-type tests and Ericsson laboratory method. Zones I, II and III show the range of category agreement for categories 1, 2 and 3, respectively. The white areas represent the zones where the titratable acidity of the saliva did not allow an allocation

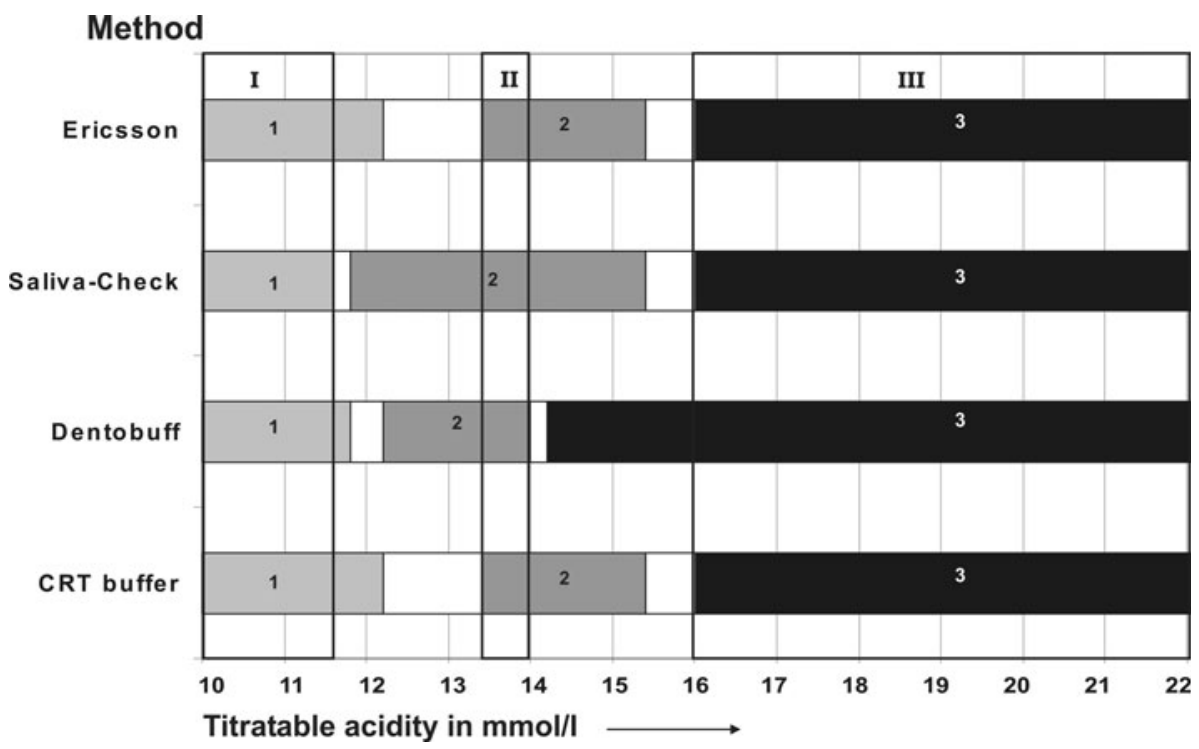

Table 3 Spearman's rank correlation between the different methods, $p<0.001$

\begin{tabular}{llllll}
\hline & CRT $^{\circledR}$ buffer test & Dentobuff strip & Saliva-check buffer & Ericsson method & Titration method \\
\hline CRT $^{\circledR}$ buffer & 1 & 0.83 & 0.88 & 0.9 & 0.83 \\
Dentobuff & & 1 & 0.85 & 0.87 & 0.83 \\
Saliva-check & & 1 & 0.95 & 0.92 \\
Ericsson & & & 1 & 0.97 \\
\hline
\end{tabular}

Table 4 Allocation of the artificial buffer solutions to the different categories using three strip-type tests as well as two laboratory test methods

\begin{tabular}{|c|c|c|c|c|c|c|c|c|}
\hline $\begin{array}{l}\text { Bicarbo- } \\
\text { nate }(\mathrm{mM})\end{array}$ & $\begin{array}{l}D i \text {-hydrogen- } \\
\text { phosphate }(\mathrm{mM})\end{array}$ & Proteins & $\begin{array}{l}\text { Titratable acidity } \\
(\mathrm{mmol} / \mathrm{l})\end{array}$ & $\begin{array}{l}\text { Ericsson } \\
\text { (rank) }\end{array}$ & $\begin{array}{l}\mathrm{CRT}^{\circledR} \text { buffer } \\
\text { (rank) }\end{array}$ & $\begin{array}{l}\text { Dentobuff } \\
\text { strip (rank) }\end{array}$ & $\begin{array}{l}\text { Saliva-check } \\
\text { buffer (rank) }\end{array}$ & $\begin{array}{l}\text { Disagreement } \\
\text { or } n . a\end{array}$ \\
\hline 5 & - & - & 3.6 & 1 & 1 & 1 & 1 & \\
\hline 10 & - & - & 7 & 1 & 1 & 1 & 1 & \\
\hline 20 & - & - & 15 & 2 & 2 & 3 & 2 & $*$ \\
\hline 40 & - & - & 30.2 & 3 & 3 & 3 & 3 & \\
\hline 60 & - & - & 47 & 3 & 3 & 3 & 3 & \\
\hline- & 3 & - & 2 & 1 & 1 & 1 & 1 & \\
\hline- & 5 & - & 3.2 & 1 & 1 & 1 & 1 & \\
\hline 5 & 5 & - & 5.8 & 1 & 1 & 1 & 1 & \\
\hline 10 & 3 & - & 8 & 1 & 1 & 1 & 1 & \\
\hline 20 & 3 & - & 18.8 & 3 & 3 & 3 & 3 & \\
\hline 40 & 3 & - & 36 & 3 & 3 & 3 & 3 & \\
\hline 60 & 3 & - & 52.9 & 3 & 3 & 3 & 3 & \\
\hline- & - & SP $0.1 \%$ & 1.1 & 1 & 1 & 1 & 1 & \\
\hline- & - & $\alpha$-Am $0.1 \%$ & 9.8 & 1 & 1 & 1 & 1 & \\
\hline- & - & Ag $0.1 \%$ Ly $0.5 \%$ & 6.4 & 1 & 1 & 1 & n.a. & $*$ \\
\hline 10 & 3 & Ag $0.1 \%$ Ly $0.5 \%$ & 13.4 & 2 & 1 & 1 & 2 & $*$ \\
\hline
\end{tabular}

Disagreements or not defined values (n.a) are marked with asterisk

Ag Amyloglucosidase from Aspergillus niger, Ly lysozyme, $\alpha$-Am $\alpha$-amylase from Bacillus subtilis, SP salivary proteins, n.a. no available colour can be evaluated according to the manufacturer's instruction 
less measuring reliability. Additionally, it can be concluded that there is a general ambiguity concerning the category ranking among studies that were done with different test systems [21-25]. This implies that a one-to-one comparison cannot be made between the data presented in those reports.

This study also highlights that further improvements are necessary for strip-type tests. Besides, it is the titratable acidity that is actually measured by these tests, and not the buffering capacity as claimed in the manual. The strip-type buffer tests are based on the method developed by Ericson and Bratthall [18], who adapted a laboratory method [26]. All of the investigated strip-type tests follow the principle of a reverse titration. The acid on the strip is neutralised by the salivary carbonate, phosphate and protein buffer systems. Each buffer molecule $\left(\mathrm{HCO}_{3}{ }^{-}, \mathrm{HPO}_{4}{ }^{2-}\right)$ neutralises one acid-derived proton $\left(\mathrm{H}_{3} \mathrm{O}^{+}\right)$. In a commercially available strip-type buffer test, the change in the buffer concentration is directly linked to the concentration change in acid-derived protons $\left(\mathrm{H}_{3} \mathrm{O}^{+}\right)$and hence the $\mathrm{pH}$. Change in the proton $\left(\mathrm{H}_{3} \mathrm{O}^{+}\right)$concentration is linked to the colour of the indicator. Depending on the extent of neutralisation of the acid on the test pad, the $\mathrm{pH}$ of the acid-saliva mixture rises (as the $\left(\mathrm{H}_{3} \mathrm{O}^{+}\right)$concentration decreases) and the indicator changes colour. The unaided human eye is able to observe a colour change when the ratio between the two colours is at least 1:10. An indicator equation $\mathrm{pH}=\mathrm{p} K_{\mathrm{a}}+$ $\log$ ( Ind $^{-} /$Hind) shows the relationship between the analysed $\mathrm{pH}$ and indicator protonation. Here, Ind $^{-}$represents the deprotonated indicator, Hind is the protonated indicator and $\mathrm{p} K_{\mathrm{a}}$ is the acid constant of the indicator. It is evident that for a visible colour change of the indicator on the test strip, the $\mathrm{pH}$ has to change by at least one unit. After neutralisation, the monitored colour of the test pad is read out and compared to a three-step colour code chart. Each colour represents a category by a label (e.g. low, medium and high). Hence, the test kits measure the titratable acidity in a logarithmic scale that is expressed as three categories. This transformation of an analogue scale into a logarithmic scale allows a fast but technically not elaborated measurement of the titratable acidity.

The buffer value $\beta$, which is not assessed by any of the commercial strip-type tests or Ericsson's laboratory method, was defined by Van Slyke with the differential equation $\beta=-\delta C / \delta \mathrm{pH}$ where $\delta C$ is the infinitesimal amount of the titrator used (acid/base), and $\delta \mathrm{pH}$ is the infinitesimal change in $\mathrm{pH}$ caused by the addition of the titrator [27]. For practical reasons, the buffer value $\beta$ is calculated as the difference quotient $\beta=-\left(C_{1}-C_{2}\right)$ $\mathrm{pH}_{1}-\mathrm{pH}_{2}$ ), which can be simplified to $\beta=-\Delta C / \Delta \mathrm{pH}$, where $\Delta C$ is the amount of the titrator used (acid/base), and $\Delta \mathrm{pH}$ is the measured change in $\mathrm{pH}$ caused by the addition of the titrator. In dental literature, the term buffer capacity has been used by some authors to describe the titratable acidity. However, the buffer capacity was defined as the "differential buffer capacity" by others to distinguish it from titratable acidity [28]. The titration method for the determination of $\beta$ has a widespread use in dental sciences. However, the buffer value $\beta$ cannot be assessed by the use of the investigated strip-type tests. Currently, there is no method other than acid/base titration of saliva to determine its buffer values, as the buffer value can be determined for each point of a titration curve. In the present study, the open system that was used for the titration experiments would allow carbon dioxide to evaporate and accordingly increase the buffer capacity significantly within the physiological $\mathrm{pH}$ range [29].

Furthermore, the results obtained with the strip-type tests may be influenced by the subjectivity of an examiner. Since variations in the colour determination of the examiners may be large, various errors can occur [30]. The viscosity of the saliva, which is related to the protein content, should also be considered as another factor that may hamper the use of strip-type tests. The viscosity may affect the size of the saliva drop added from the supplied pipette and thus change the surface wetting for saliva. The latter can influence the final colour of the indicator obtained after $5 \mathrm{~min}$ of incubation. Furthermore, the saliva drop tested on the strips was clearly excessive for CRT buffer and saliva-check tests, since the excess of saliva had to be removed. The results would then depend on the rate at which acid diffused out of the strip into the saliva and the time interval before the excess of saliva was removed. The latter might lead to detection error.

All strip-type tests were able to assign the prepared hydrogencarbonate and $d i$-hydrogenphosphate to the correct buffer categories of low, medium and high. Only in case of $20 \mathrm{mmol} / \mathrm{l}$ hydrogencarbonate, the buffering capacity was judged as high (category 3) by the Dentobuff strip test, whereas all other test systems referred to category 2 . Thus, the definition of the measured categories by Dentobuff strip test differs compared to the other applied test systems (Fig. 1).

The protein buffer system seems to play a more significant role than previously reported [10, 16]. The total protein concentration of amyloglucosidase and lysozyme was at the upper limit of salivary protein concentrations defined in the literature. The concentration of $0.1 \%$ amyloglucosidase was significantly lower in contrast to $0.5 \%$ lysozyme content. However, $81 \%$ of the protein buffering capacity at $\mathrm{pH} 4.3$ is based on amyloglucosidase [16]. The concentration of amyloglucosidase alone did not exceed the protein content typically found in stimulated saliva. All strip-type tests were able to correctly assign salivary protein buffer solution of $0.1 \%$ concentration as well as $0.1 \%$ amylase. However, when a mixture of $0.1 \%$ amyloglucosidase and $0.5 \%$ lysozyme was applied, none of 
the test systems worked accurately. This mixture was shown to provide almost identical buffer attributes as human salivary protein [16]. We speculate that the lower surface tension of the high protein saturated solutions could have an impact on the buffer capacity detection. It has been suggested earlier that the surface tension of a solution is connected to the buffer properties of the dissolved substance in case of non-physiological media [31-33]. Therefore, one can assume that there is a relation between the detected buffer value of saliva and physical parameters such as surface tension or refractive index. To the best of our knowledge, this is the first report to describe the connection between the measured buffering capacity and physical properties of saliva. More investigations will be carried out to elucidate this relationship. Particularly, surface tension of protein solutions can be varied to study its role in the detection of salivary buffering capacity of physiological fluids. Further experimental study and results will be published elsewhere. Future research on this topic will contribute to the development of fast, reliable and compatible methods for unambiguous assessment of human salivary buffering capacity.

In summary, within the limits of the current research, it is concluded that there is a best agreement among results provided by strip-type systems in patients with high buffering capacity. However, certain disagreement of the buffering capacity was observed for patients with medium or low values. In addition, categories may differ from each other since "low" buffering capacity in one brand is labelled as "medium" in another. Those findings should be taken into consideration when diagnosing the caries and/or erosion risks of a patient with medium or low buffering capacity as well as when comparing results from different dentists or research fields, such as clinical trials. Furthermore, this study shows that the presence of proteins in the analysed solution has an impact on the determination of the buffering capacity by the colorimetric test.

Acknowledgments This study was supported by the University of Bern, Switzerland. We thank Dr. Stefanie Hayoz from the Institute of Mathematical Statistics and Actuarial Science, University of Bern for the statistical data analysis and Dr. Ekaterina Rakhmatullina, Department of Preventive, Restorative and Pediatric Dentistry, University of Bern, for help in revision of the manuscript.

\section{References}

1. Zandona AF, Zero DT. Diagnostic tools for early caries detection. J Am Dent Assoc. 2006;137:1675-84.

2. Lussi A, Jaeggi T. Erosion-diagnosis and risk factors. Clin Oral Investig. 2008;12:5-13.

3. Leone CW, Oppenheim FG. Physical and chemical aspects of saliva as indicators of risk for dental caries in humans. J Dent Educ. 2001;65:1054-62.
4. Fejerskov O, Thylstrup A. Different concepts of dental caries and their implications. In: Thylstrup A, Fejerskov O, editors. Textbook of clinical cariology. Copenhagen: Munksgaard; 1994. pp. 209-18.

5. Lussi A. Erosive tooth wear-a multifactorial condition of growing concern and increasing knowledge. In: Lussi A, editor. Dental erosion from diagnosis to therapy. Basel: Karger; 2006. p. $1-8$.

6. Edgar WM, Higham SM. Role of saliva in Caries models. Adv Dent Res. 1995;9:235-8.

7. Dawes C. Salivary flow patterns and the health of hard and soft oral tissues. J Am Dent Assoc. 2008;139:18S-24S.

8. Gopinath VK, Arzreanne AR. Saliva as a diagnostic tool for assessment of dental caries. Arch Orofac Sci. 2006;1:57-9.

9. Holbrook WP, Furuholm J, Gudmundsson K, Theodòrs A, Meurman JH. Gastric reflux is a significant causative factor of tooth erosion. J Dent Res. 2009;88:422-6.

10. Bardow A, Moe D, Nyvad B, Nauntofte B. The buffer capacity and buffer systems of human whole saliva measured without loss of CO2. Arch Oral Biol. 2000;45:1-12.

11. Lenander-Lumikari M, Loimaranta V. Saliva and dental caries. Adv Dent Res. 2000;14:40-7.

12. Ericsson Y. Clinical investigations of the salivary buffering action. Acta Odontol Scand. 1959;17:131-65.

13. Moritsuka M, Kitasako Y, Burrow MF, et al. Quantitative assessment for stimulated saliva flow rate and buffering capacity in relation to different ages. J Dent. 2006;34:716-20.

14. Bratthall D, Tynelius-Bratthall G. Diagnostika als Grundlage kausaler Behandlung Professionelle Prävention in der Zahnartzpraxis 1994:63-64.

15. Nagler RM, Hershkovich O. Relationships between age, drugs, oral sensorial complaints and salivary profile. Arch Oral Biol. 2005;50:7-16.

16. Lamanda A, Cheaib Z, Turgut MD, Lussi A. Protein buffering in model systems and in whole human saliva. PLoS ONE. 2007;2: 263 .

17. Bradford MM. A rapid and sensitive method for the quantitation of microgram quantities of protein utilizing the principle of protein-dye binding. Anal Biochem. 1976;72:248-54.

18. Ericson D, Bratthall D. Simplified method to estimate salivary buffer capacity. Scand J Dent Res. 1989;97:405-7.

19. Messer LB. Assessing caries risk in children. Aust Dent J. 2000;45:10-6.

20. Lussi A, Jaeggi T, Zero D. The role of diet in the aetiology of dental erosion. Caries Res. 2004;38(Suppl 1):34-44.

21. Attin T, Knöfel S, Buchalla W, Tütüncü R. In situ evaluation of different remineralization periods to decrease brushing abrasion of demineralized enamel. Caries Res. 2001;35:216-22.

22. Ertuğrul F, Elbek-Cubukçu C, Sabah E, Mir S. The oral health status of children undergoing hemodialysis treatment. Turk $\mathrm{J}$ Pediatr. 2003;45:108-13.

23. Kitasako Y, Moritsuka M, Foxton RM, et al. Simplified and quantitative saliva buffer capacity test using a hand-held $\mathrm{pH}$ meter. Am J Dent. 2005;18:147-50.

24. Leung KC, McMillan AS, Leung WK, et al. Oral health condition and saliva flow in southern Chinese with Sjögren's syndrome. Int Dent J. 2004;54:159-65.

25. Meurman JH, Rantonen P. Salivary flow rate, buffering capacity, and yeast counts in 187 consecutive adult patients from Kuopio, Finland. Scand J Dent Res. 1994;102:229-34.

26. Ericsson Y. Clinical determination of salivary buffering. Sven Tandlak Tidskr. 1953;46:379-86.

27. Van Slyke D. On the measurement of buffer values and the relationship of buffer value to the dissociation constant of the buffer and the concentration and reaction of the buffer solution. J Biol Chem. 1922;52:525-70. 
28. Barbour ME, Shellis RP. An investigation using atomic force microscopy nanoindentation of dental enamel demineralization as a function of undissociated acid concentration and differential buffer capacity. Phys Med Biol. 2007;52:899-910.

29. Izutsu KT. Theory and measurement of the buffer value of bicarbonate in saliva. J Theor Biol. 1981;90:397-403.

30. McMaugh D. A comparative analysis of the colour matching ability of dentists, dental students, and ceramic technicians. Aust Dent J. 1977;22:165-7.
31. Vazquez G, Alvarez E, Navaza JM. Density, viscosity, and surface tension of sodium carbonate + sodium bicarbonate buffer solutions in the presence of glycerine, glucose and sucrose from 25 to $40^{\circ} \mathrm{C}$. J Chem Eng Data. 1998;43:128-32.

32. St Jonston JH. The Surface tension of protein solutions. Part III. Biochem J. 1927;13:1314-27.

33. Hammershøj M, Prins A, Qvist KB. Influence of $\mathrm{pH}$ on surface properties of aqueous egg albumen solutions in relation to foaming behaviour. J Sci Food Agric. 1998;79:859-68. 